\title{
Diversity and abundance of littoral cladocerans and copepods in nine Ecuadorian highland lakes
}

\author{
Leticia E. Torres ${ }^{1} \&$ Kent Rylander ${ }^{2}$ \\ 1 Department of Biological Sciences, Texas Tech University, Lubbock, Texas 79409-3131; leticia.torres@ttu.edu \\ 2 Field Research Station, Texas Tech University - Junction Campus, P.O. Box 186. Junction, Texas 76849; \\ k.rylander@ttu.edu
}

Received 04-II-2005. Corrected 05-VIII-2005. Accepted 09-IX-2005.

\begin{abstract}
The diversity and abundance of littoral cladocerans and copepods were studied in nine lakes at Reserva Ecológica Cayambe-Coca (Páramo de Guamaní), Ecuador. Six samples were taken in the littoral zone of each lake using a $500 \mu \mathrm{m}$ mesh plankton conic net. One species of cladocerans (Ephemeroporus acanthoides) is reported for the first time in Ecuador. The diversity ( $\left.\mathrm{H}^{\prime}\right)$ and evenness $(\mathrm{E})$ of the lakes were determined and correlated with PCA axes based on their environmental variables. The principal parameters that distinguished these lakes were altitude and $\mathrm{pH}$, an unexpected finding considering that the altitudinal range was very small. Lake size is of secondary importance for this group of lakes. None of the environmental axes correlated with H' or E; nevertheless, a larger than expected species richness was found in a small oligotrophic lake with a high level of DO. Based on our results, we hypothesize that altitude and $\mathrm{pH}$ are important factors determining the zooplankton diversity (directly or indirectly) in highland lakes. Rev. Biol. Trop. 54(1): 131-137. Epub 2006 Mar 31.
\end{abstract}

Key words: Andes, Ecuador, lakes, microcrustaceans, zooplankton.

The páramo, one of the various ecosystems in the northern Andean region, ranges in altitude between 3200 and $4700 \mathrm{~m}$ above the limit of Andean forests and below the limit of perpetual snow (Lauer 1979). Lotic and lentic freshwater ecosystems are numerous and widespread in the páramos and represent unique habitats due to their natural isolation (Kiersch et al. 2004).

The most notable studies of the ecology of plankton in high altitude Andean lakes occurred during the late seventies and eighties. They included surveys (Widmer et al. 1975), preliminary studies of the relationship between zooplankton and environment (Colvinaux and Steinitz 1980), and preliminary assessment of the trophic relationships affecting the diversity of zooplankton (Hurlbert et al. 1986).

Most studies of freshwater ecosystems in the Ecuadorian páramos have focused on aquatic insects and their adaptation to lotic environmental variables. The species richness of aquatic insects has been analyzed according to temperature, oxygen supply, altitude and latitude. Results suggested that the number of insect orders and families increase with maximum stream temperature, and decrease with altitude and latitude (Jacobsen et al. 1997, Sites et al. 2003), and that the tropical highland streams are more sensitive to lower oxygen levels than their temperate counterparts because of the low partial pressure of oxygen at an altitude of $3000 \mathrm{~m}$ (Jacobsen 1998, 2000, Jacobsen et al. 2003). No studies on planktonic fauna of Ecuadorian high altitude lakes exist in spite of the importance of this group in the trophic chain of aquatic communities.

The objectives of this study were to (a) survey the microcrustacean plankton fauna (cladocerans and copepods) in the study area, (b) determine their diversity and abundance, and (c) attempt to determine the effect of environmental conditions on diversity. 


\section{METHODOLOGY}

Study area: The study site was the Reserva Ecológica Cayambe-Coca (Páramo de Guamaní) in Ecuador, between $78^{\circ} 07^{\prime} 00^{\prime \prime}$ and $78^{\circ} 12^{\prime} 00^{\prime \prime} \mathrm{W}$, and $0^{\circ} 16^{\prime} 00^{\prime \prime}$ and $0^{\circ} 21^{\prime} 00^{\prime \prime} \mathrm{S}$, three kilometers north of the village of Papallacta. Annual precipitation ranges between 1000 and $1500 \mathrm{~mm}$, and relative humidity reaches $98 \%$ most of the year. Median temperature is $6.4^{\circ} \mathrm{C}$, but diurnal temperatures fluctuate considerably (Terneus 2002).

We selected nine highland lakes of glacial origin on the basis of size. Mogotes II, Guaitaloma, Gemela I, Gemela II, Antena I, and Antena II are oligotrophic and do not receive organic pollutants. The lakes with larger basins (i.e., Loreto, Mogotes I and Sucus) are dammed and constitute part of the hydrological system that distributes water to surrounding urban areas. These lakes are catalogued as mesotrophic because of the decomposition of submerged organic matter due to damming, and because of the lack of optimal thermal dynamics, circumstances that do not allow the recycling of nutrients occurring under natural conditions (Terneus 2004). The lakes are situated between 3750 and $4097 \mathrm{~m}$.

Specimen collection: In June 2003, six zooplankton samples were taken in the littoral zone of each lake using a $500 \mu \mathrm{m}$ mesh plankton conic net with a $40 \mathrm{ml}$ jar and a frame of $12 \mathrm{~cm}$ in diameter attached to a two-meter long stick. Approximately $20 \mathrm{ml}$ of ethanol were added to each sample for preservation purposes. Specimens were sorted to morphospecies and counted at the Department of Biological Sciences at Texas Tech University. Dr. Leszek Bledzki, Mount Holyoke College, identified the specimens, utilizing previous studies (Bledzki 2004, Dussart 1967, Dussart 1969, Flesner 1972, Smirnov 1974, Reid 1985, Gaviria 1988, 1989, 1994, Bayly 1992, Hebert 1995, Smirnov 1996, Korinek 1999, Dussart and Defaye 2001), when appropriate.

Analyses: Dissolved oxygen content (DO), temperature, conductivity and $\mathrm{pH}$ of the water were measured with a Hydrolab $8700^{\mathrm{TM}}$. Lake sizes were categorized as large ( $>21$ hectares), medium (6-20 hectares) and small (0-5 hectares), and defined as 1, 2, or 3 respectively for the purposes of analyses. Shannon diversity index (H') and Evenness (E) were calculated for each lake, and a dissimilarity analysis between lakes was established using Matlab (Strauss 2004). Lake Antena I was excluded from this analysis because the statistical function of the program does not allow for analysis of a locality with only one species.

Principal Components Analysis (PCA), based on environmental variables, was performed to detect links between the size of the lakes and each variable (SPSS, 7.5). The environmental variables included were size, altitude, conductivity, temperature, DO and pH. Subsequently, Correlation Analysis was used to detect inter-relationship between $\mathrm{H}^{\prime}$ and E (the dependent variables) and the PCA axes. Finally, Cluster Analysis was performed to identify similarities between lakes based on the environmental variables, $\mathrm{H}^{\prime}$ and $\mathrm{E}$. With the exception of the dissimilarity matrices, all statistical analyses were performed with SPSS.

\section{RESULTS}

Nine species were recorded in the nine lakes. Three species were found only in the small lakes: Alona (Biapertura) affinis (Leydig 1860), Ephemeroporus acanthoides Frey 1982, and Bryocamptus sp. (?). Antena II registered the largest number of species and individuals (Table 1). The dissimilarity analysis based on $\mathrm{H}^{\prime}$ and $\mathrm{E}$ showed very highly significant differences in the diversity between Antena II and the lakes Mogotes I and Gemela II (Table 2). With regard to E, Antena II differed significantly from all other lakes. Highly significant statistical differences were also found in $\mathrm{E}$ between Sucus and Guaitaloma.

Table 3 summarizes the environmental variables of the lakes used to perform the PCA. The first component (altitude and $\mathrm{pH}$ ) explained $51.5 \%$ of the variance, and the second (oxygen and size) explained 31.8\% (Table 
TABLE 1

Total species and number of individuals registered for each lake

\begin{tabular}{|c|c|c|c|c|c|c|c|c|c|}
\hline Species & $\underset{\tilde{U}}{\mathscr{J}}$ & $\begin{array}{l}\stackrel{8}{0} \\
0 \\
0 \\
0\end{array}$ & $\begin{array}{l}\overrightarrow{0} \\
0 \\
0 \\
0 \\
0 \\
0\end{array}$ & $\begin{array}{l}= \\
0 \\
0 \\
0 \\
0 \\
0 \\
0\end{array}$ & $\frac{\widetilde{J}}{\tilde{\Xi}}$ & $\begin{array}{l}\vec{\pi} \\
\frac{\pi}{0} \\
\overline{0} \\
0\end{array}$ & 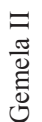 & $\frac{\widetilde{J}}{\mathbb{0}}$ & 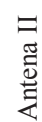 \\
\hline
\end{tabular}

Cladocera:

$\begin{array}{lccccccccc}\text { Alona guttata } & 32 & 4 & 2 & 0 & 0 & 56 & 0 & 0 & 0 \\ \text { Alona (Biapertura) affinis } & 0 & 0 & 0 & 0 & 0 & 0 & 0 & 0 & 1 \\ \text { Chydorus sphaericus } & 9 & 1 & 1 & 17 & 53 & 15 & 2 & 0 & 0 \\ \text { Daphnia ambigua } & 1 & 0 & 1 & 0 & 0 & 0 & 1 & 0 & 92 \\ \text { Ephemeroporus acanthoides } & 0 & 0 & 0 & 0 & 0 & 0 & 0 & 0 & 1 \\ \text { Macrothrix sp. (?) } & 0 & 0 & 0 & 2 & 0 & 0 & 0 & 0 & 0\end{array}$

Copepoda:

$\begin{array}{llllllllcc}\text { Boeckella occidentalis intermedia } & 0 & 1 & 0 & 0 & 0 & 0 & 0 & 623 & 1380 \\ \text { Metacyclops leptopus leptopus } & 0 & 0 & 4 & 7 & 83 & 0 & 0 & 0 & 0 \\ \text { Bryocamptus sp. (?) } & 0 & 0 & 0 & 0 & 0 & 0 & 0 & 0 & 3\end{array}$

TABLE 2

Dissimilarity values of diversity (upper the diagonal) and evenness (under the diagonal) of the lakes

\begin{tabular}{lcccccccc} 
& Sucus & Loreto & Mogotes I & Mogotes II & Guaitaloma & Gemela I & Gemela II & Antena II \\
\multicolumn{1}{c}{ Sucus } & --- & 0.2413 & 0.5867 & 0.2021 & 0.0423 & 0.1106 & 0.0102 & 0.3479 \\
Loreto & 0.2196 & --- & 0.3454 & 0.0392 & 0.1989 & 0.3519 & 0.2310 & $0.5892^{* *}$ \\
Mogotes I & 0.3049 & 0.0853 & --- & 0.3846 & 0.5444 & $0.6974 *$ & $0.5765^{*}$ & $0.9347 * * *$ \\
Mogotes II & 0.1840 & 0.0357 & 0.1210 & --- & 0.1598 & 0.3128 & 0.1919 & $0.5500^{*}$ \\
Guaitaloma & $0.3945^{* * *}$ & 0.1749 & 0.0896 & 0.2106 & --- & 0.1530 & 0.0321 & $0.3903 * * *$ \\
Gemela I & 0.1738 & 0.0458 & 0.1311 & 0.0101 & $0.2207 *$ & --- & 0.1209 & 0.2373 \\
Gemela II & 0.3482 & 0.1286 & 0.0433 & 0.1643 & 0.0463 & 0.1744 & --- & $0.3582^{* * *}$ \\
Antena II & $0.4270^{* * *}$ & $0.6466^{* * *}$ & $0.7320^{* * *}$ & $0.6110^{* * *}$ & $0.8216^{* * *}$ & $0.6009 * * *$ & $0.7753^{* * *}$ & ---
\end{tabular}

$(* \mathrm{p}<0.05 ; * * 0.01<\mathrm{p}<0.05 ; * * * \mathrm{p}<0.001)$.

4) (Fig. 1). The highest lakes are also the more acidic, and the small lakes presented the highest levels of DO. Altitude and $\mathrm{pH}$ seem to be the strongest discriminant factors between lakes; nevertheless, neither plankton diversity $\left(H^{\prime}\right)$ nor E were significantly correlated with the first component $(p>0.05)$; similarly, there was no significant correlation between the oxygen content and size axis with $\mathrm{H}^{\prime}$ or $\mathrm{E}$ of the lakes ( $p>0.05)$. Cluster Analysis based on the environmental variables, H' and $\mathrm{E}$ showed two main groups separated principally by altitude (Fig. 2). Antena I, the highest lake, showed similarities to the second group. 
TABLE 3

Physicochemical characteristics of the lakes

$\begin{array}{lcccccc} & \text { Size } & \begin{array}{c}\text { Altitude } \\ (\mathrm{m})\end{array} & \begin{array}{c}\text { Temperature } \\ \left({ }^{\circ} \mathrm{C}\right)\end{array} & \begin{array}{c}\text { Conductivity } \\ (\mathrm{mS} / \mathrm{cm})\end{array} & \begin{array}{c}\text { D. O. } \\ (\mathrm{mg} / \mathrm{l})\end{array} & \mathrm{pH} \\ \text { Sucus } & 1 & 3840 & 9.50 & 0.114 & 6.34 & 7.50 \\ \text { Loreto } & 1 & 3750 & 9.04 & 0.094 & 5.99 & 7.38 \\ \text { Mogotes I } & 1 & 4012 & 8.75 & 0.066 & 6.17 & 6.59 \\ \text { Mogotes II } & 2 & 3850 & 8.60 & 0.062 & 6.57 & 7.37 \\ \text { Guaitaloma } & 3 & 4000 & 8.10 & 0.060 & 6.69 & 7.20 \\ \text { Gemela I } & 3 & 3800 & 9.83 & 0.094 & 7.56 & 7.53 \\ \text { Gemela II } & 3 & 3750 & 11.30 & 0.033 & 7.30 & 7.20 \\ \text { Antenas I } & 3 & 4097 & 5.89 & 0.012 & 6.72 & 6.27 \\ \text { Antenas II } & 3 & 4034 & 9.25 & 0.018 & 6.27 & 6.97\end{array}$

Lake sizes were categorized as 1(>21 hectares), 2 (6-20 hectares), and 3 (0-5 hectares)

TABLE 4

Three components extracted using the PCA

\begin{tabular}{lccc} 
& \multicolumn{3}{c}{ Component } \\
& 1 & 2 & 3 \\
Altitude & -0.918 & -0.168 & 0.086 \\
Conductivity & 0.803 & -0.396 & 0.403 \\
Oxygen & 0.146 & 0.908 & 0.274 \\
pH & 0.908 & 0.143 & 0.145 \\
Size & -0.411 & 0.875 & 0.084 \\
Temperature & 0.767 & 0.34 & -0.498 \\
Total variance & 51.522 & 31.845 & 8.675 \\
Explained $(\%)$ & & &
\end{tabular}

\section{DISCUSSION}

This record of Ephemeroporus acanthoides Frey 1982 appears to be the first for Ecuador (Bledzki, per.com.). In general, the lakes registered a relatively low number of species, which was expected, since compared with other tropical ecosystems, páramos generally present low species diversity and high endemism rates (Luteyn 1992).

The principal parameter distinguishing these lakes was altitude, an unexpected finding considering that the altitudinal range is very small (347 m). Although Dodson et al. (2000) attribute higher species richness to larger 


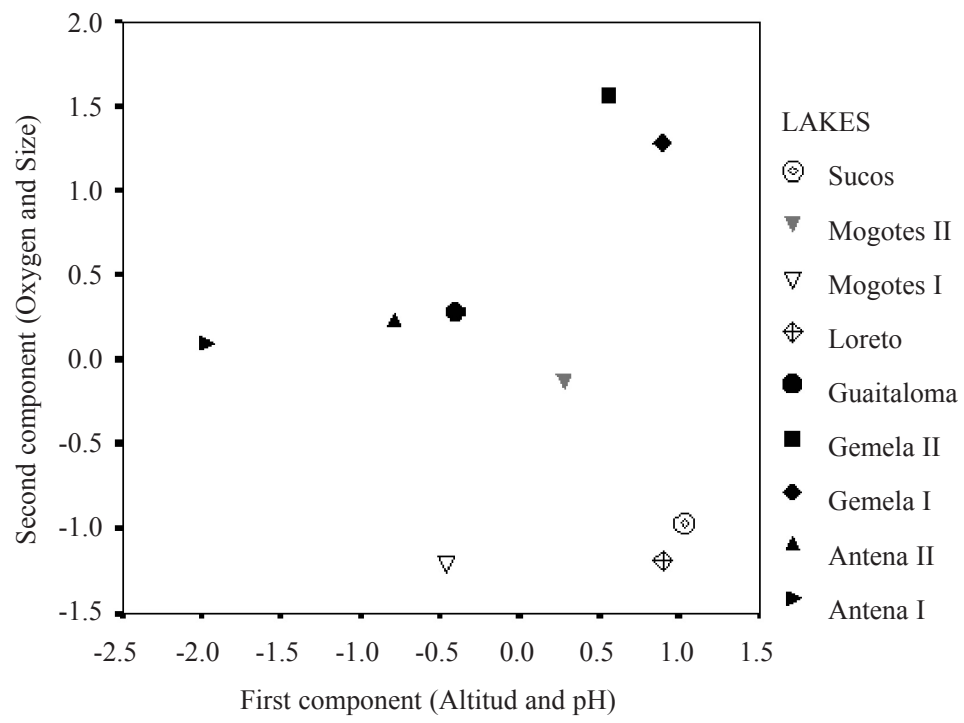

Fig. 1. PCA based on environmental variables.

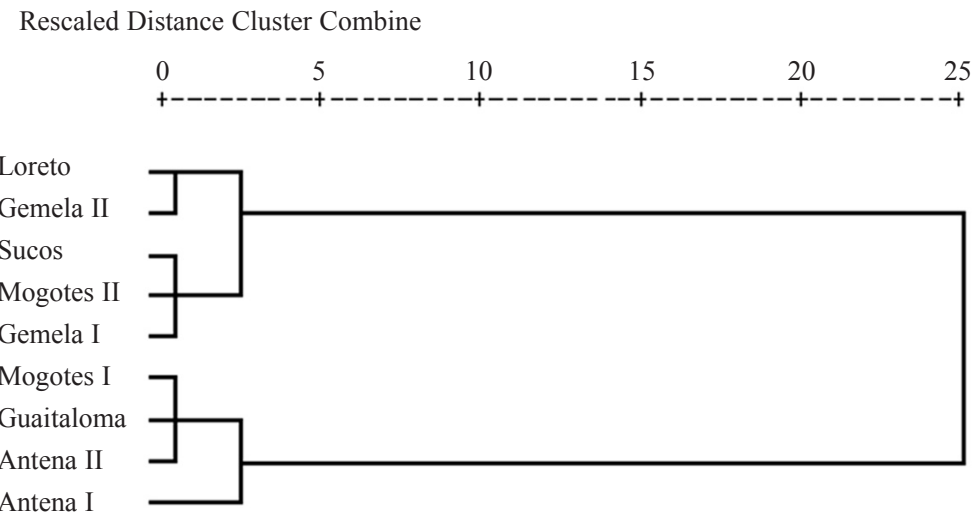

Fig. 2. Hierarchical cluster analysis based on diversity, evenness and environmental characteristics. Dendrogram using Average Linkage (Between Groups).

mesotrophic lakes, which contain more distinct habitats and more resources than smaller lakes, we found a higher number of species in a small oligotrophic lake. Lake Antena II registered the highest number of species richness and greatest abundance with the copepod B. o. intermedia and the cladocera $D$. ambigua dominating. This lake and Antena I are located at the highest altitudes in the study area and also are the lakes with the lowest conductivity values.
Antena I and II are oligotrophic with a rocky substract, without aquatic vegetation in their littoral zone; they contain a very different zooplankton species composition. Although both are in the category of small lakes, Antena II is approximately three times the size of Antena I (which is the smallest lake sampled) and its water comes from surface springs, in contrast to Antena I, whose water comes mainly from underground springs. 
The $\mathrm{pH}$ and DO are not limiting factors because the lakes have high oxygen content and $\mathrm{pH}$ levels within the range proposed for the survival of nearly all species of zooplankton (Grant 2001). The highest lakes were also the more acidic due to the geologic composition of the area (Terneus, per. com.); and, on the other hand, the higher level of DO in the small lakes results from wind action that allows an easier mixture of the water layers. Differences between dammed lakes and the ones in natural state are not conclusive. More studies are required to establish an effect of damming in the planktonic fauna; nevertheless, it is important to point out that the lake with the highest number of species was in natural conditions.

Our findings stress the necessity for longterm studies on a large number of lakes in order to elucidate the ecological dynamics of these isolated ecosystems. Likewise, it is necessary to study other patches of páramo, such as 'El Angel,' on the northern extreme of Ecuador. Comparing both regions would allow further testing of hypotheses that relate size, geological and altitudinal patterns of highland lakes to their influence on planktonic fauna. Based on our results, we hypothesize that altitude and $\mathrm{pH}$ are important factors determining the zooplankton diversity (directly or indirectly) in highland lakes.

\section{ACKNOWLEDGMENTS}

We gratefully acknowledge Oscar Pérez for his help in the obtaining of collecting permits; Esteban Terneus, President of the Fundación Agua, for his assistance and logistic support during the field work, and for his comments to this manuscript; Leszek Bledzki for his help in the verification and identification of specimens and for providing helpful information about distribution of some groups; and Richard Strauss and Sergio Solari for their aid in the analyzes of the data. Jorge Salazar-Bravo, Stanley Dodson, René Fonseca, Sharon Myers, Norma Salcedo, Hugo Mantilla, Jon Dunnum and Joseph Carmichael for their invaluable comments and suggestions to this manuscript. This research was supported by the Plum Foundation.

\section{RESUMEN}

La diversidad y abundancia de cladóceros y copépodos de la zona litoral de nueve lagos fue estudiada en la Reserva Ecológica CayambeCoca (Páramo de Guamaní), Ecuador. Seis muestras fueron tomadas en la zona litoral de cada lago utilizando una red conica para plancton de $500 \mu \mathrm{m}$ de apertura. Una especie de cladócero (Ephemeroporus acanthoides) es informada por primera vez en Ecuador. La diversidad (H') y equitatividad (E) fueron determinadas y correlacionadas con los ejes del PCA basado en variables ambientales de los lagos. Los principales parámetros que distinguen estos lagos fueron la altitud y el $\mathrm{pH}$, hallazgo inesperado dado el estrecho ámbito altitudinal. El tamaño parece ser secundario en importancia para este grupo de lagos. No se encontró una correlación significativa entre ninguno de los ejes ambientales y los indices H' o E; sin embargo, la riqueza de especies fue mayor en un pequeño lago oligotrófico con altos niveles de DO.

Palabras clave: Andes, Ecuador, lagos, microcrustáceos, zooplankton.

\section{REFERENCES}

Bayly, I.A.E. 1992. The non-marine Centropagidae. (Copepoda: Calanoida) of the world. Guides to the Identification of the Macroinvertebrates of the Continental Waters of the World. SPB Academic Publishing, Amsterdam. 30 p.

Colinvaux, P. \& M. Steinitz.1980. Species richness and area in Galapagos and Andean lakes: equilibrium phytoplankton communities and a paradox of the zooplankton, p.697-712. In W.C. Kerfoot (ed.). Evolution and ecology of zooplankton communities. University Press of New England Hannover, New Hampshire.

Dodson S.I., S. Arnott \& K. Cottingham. 2000. The relationship in lake communities between primary 
productivity and species richness. Ecology 81: 26622679.

Dussart, B. 1967. Les Coppodes des eaux continentales d'Europe occidentale. Tome I: Calanoides at Harpacticoides. N. Boube, Paris. 500 p.

Dussart, B. 1969. Les Coppodes des eaux continentales d'Europe occidentale. Tome II: Cyclopoides et Biologie. N. Boube, Paris. 292 p.

Dussart, B. H. \& D. Defaye. 2001. Copepoda. Introduction to the Copepoda, p. 1-344. In H.J.F Dumont (ed.). Guides to the identification of the macroinvertebrates of the continental waters of the world. Backhuys, Leiden, Holland.

Flesner, D. 1972. Krebstiere, Crustacea, Kiemen und Blattfssler, Branchiopoda, Fischläuse, Branchiura. G. Fisher, Jena, Germany.

Gaviria, S. 1989. The calanoid fauna (Crustacea, Copepoda) of the Cordillera Oriental of the Colombian Andes. Hydrobiologia 178: 113-134.

Grant, D. 2001. Pennak's Freshwater invertebrates of the United States: Porifera to Crustacea. Wiley \& Sons, New York. 648 p.

Hebert, P.D.N. 1995. The Daphnia of North America: An illustrated fauna (CD-ROM distributed by the author, Department of Zoology, University of Guelph, Guelph, Ontario, Canada). CD-ROM University of Guelph.

Hurlbert, S.H., W. Loayza \& T. Moreno. 1986. Fish-flamingo-plankton interactions in the Peruvian Andes. Limnol. and Oceanogr. 31: 457-468.

Hydrolab 8700 Cameron Road, Suite 100. Austin, TX, 78754

Jacobsen, D., R. Shultz \& A. Encalada. 1997. Structure and diversity of stream macroinvertebrates assemblages: the effect of temperature with altitude and latitude. Freshwater Biol. 38: 247-261.

Jacobsen, D. 1998. The effect of organic pollution on the macroinvertebrate fauna of Ecuadorian highland streams. Arch. Hydrobiol. 143: 179-195.

Jacobsen, D. 2000. Gill size of trichoptera larvae and oxygen supply in streams along a $4000 \mathrm{~m}$ gradient of altitude. J. North Amer. Benthol. Soc. 19: 329-343.

Jacobsen, D. \& E. Terneus. 2001. Aquatic macrophytes in cool aseasonal and seasonal streams: a comparison between Ecuadorian highland and Danish lowland streams. Aquatic Bot. 71: 281-295.

Jacobsen, D., S. Rostgaard \& J.J. Vasconez. 2003. Are macroinvertebrates in high altitude streams affected by oxygen deficiency? Freshwater Biol. 48: 2025 2032.

Kiersch, B., R. Mühleck \& G. Gunkel. 2004. Las macrófitas de algunos lagos alto-andinos del Ecuador y su bajo potencial como bioindicadores de eutrofización. Rev. Biol. Trop. 52: 829-837.

Korinek, V. 1999. A guide to limnetic species of Cladocera of African inland waters (Crustacea, Branchiopoda) (Using the morphology of parthenogenetic females). Occasional Publication SIL, 1: 1-57.

Luteyn, J. 1992. Paramos: Why study them?, p. 1-14. In H. Balslev \& J. Luteyn (eds.). Paramo: An Andean Ecosystem under human influence. Academic, London.

Reid, J.W. 1985. Chave de identificação e lista de referências bibliográficas para as espécies continentais sulamericanas de vida livre da ordem Cyclopoida (Crustacea, Copepoda). Bol. Zool., Sao Paulo, 9: 17-143.

Sites, R.W., M.R. Willig \& M.J. Linit. 2003. Macroecology of aquatic insects: a quantitative analysis of taxonomic richness and composition in the Andes mountains of northern Ecuador. Biotropica 35: 226-239.

Smirnov, N.N. 1974. Chydoridae. Israel Program for Scientific Translations, Keter Publish. House, Jerusalem. 644 p.

Smirnov, N.N. 1996. Cladocera: the Chydorinae and Sayciinae (Chydoridae) of the world, p. 1-197. In H.J.F. Dumont (ed.). Guides to the identification of the macroinvertebrates of the continental waters of the world. SPB Academic, Amsterdam.

SPSS for Windows, Release 7.5, Standard version.

Terneus, E. 2002. Estudio básico de biología acuática en el embalse de Mogotes-Papallacta. Fundación Agua. Quito, Ecuador.

Terneus, E. 2004. Estudion básico de biología acuática en el Embalse de Mogotes. Empresa Municipal de Agua Potable y Alcantarillado, Quito.

Widmer, C., T. Kittel \& P.J. Richardson. 1975. A survey of the biological limnology of Lake Titicaca. Verhandlungen. Internationale Vereinigung fuer theoretische und angewandte Limnologie. 19: 1504-1510.

\section{INTERNET REFERENCE}

Strauss, R. 2004. Matlab functions and script files (Consulted: June 17, 2004, http://www.biol.ttu.edu/ strauss/Matlab/Catalog.PDF). 
